Animal Health Research Institute, Mansoura Laboratory

\title{
SOME STUDIES ON VIBRIOSIS IN FARMED MUGIL CEPHALUS IN DAKAHLIA GOVERNORATE
}

(With 5 Tables)

By

\author{
M.M. ABD EL-LATIF; A.H. MOUSTAFA \\ and RAWIA S.M. ADAWY
}

(Received at 10/6/2008)

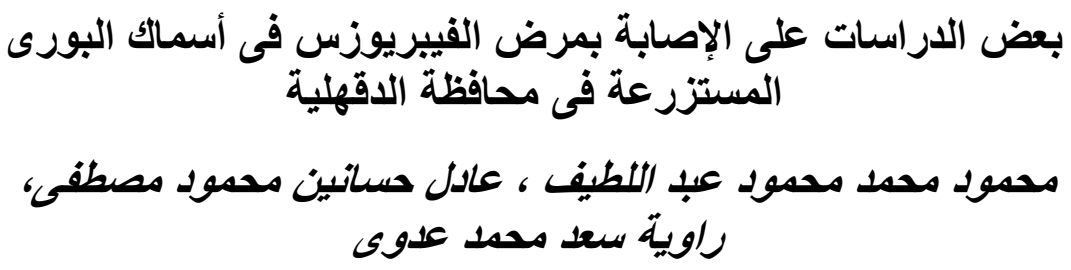

أجريت هذه الدراسة على عدد 80 سمكة من أسماك البورى المستزر عة في محافظة الدقهلية وبالفحص الظاهرى تبين وجود أنزفة واحتقان على الجلد و و

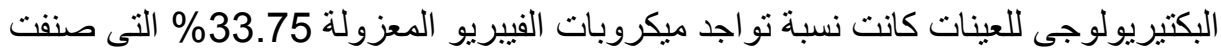

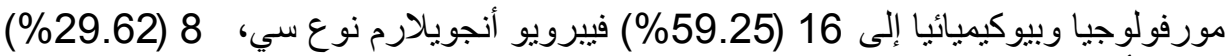

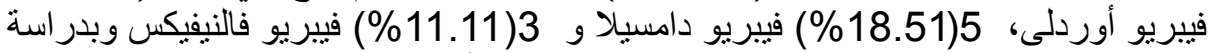

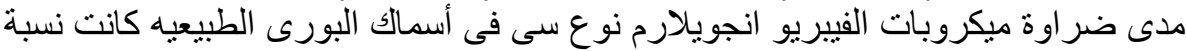

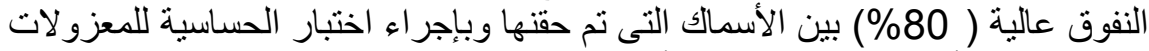

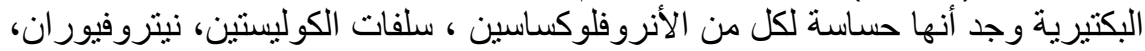
أوكسى تتر اسيكلين، تتر اسيكلين وسيفو تاكسيح.

\section{SUMMARY}

80 naturally infected farmed Mugil Cephalus were collected from a private fish farm at Dakahlia Governorate, revealed clinically congestion and haemorrhages on skin and fins rot. The fish were examined bacteriologically for detection of Vibrio species. The obtained results revealed that $27(33.75 \%)$ were positive for Vibrio species which identified morphologically and biochemically to $V$. anguillarum biotype C 16 (59.25\%), V. ordalii 8(29.62\%), V. damsela 5 (18.51\%) and V. vulnificus 3(11.11\%). The pathogencity of isolated $V$. anguillarum biotype $\mathrm{C}$ strains in Mugil fish revealed high mortality (80\%) in experimentally healthy fish. Sensitivity test of the isolated strains showed that Vibrio spp. were sensitive for Enrofloxacin, Colistin sulphate, Nitrofurantoin, Oxytetracycline, Tetracycline and Cefotaxim.

Key words: Mugil cephalus, vibriosis, fish diseases 


\section{INTRODUCTION}

Fish are regarded as being most popular and more perishable than other high protein foods. The flesh of healthy fish is considered bacteriologically sterile. However, they are sometimes contaminated with bacterial pathogens and thus can inflect heavy losses in fish and causing diseases in man. Vibriosis is an enzootic disease of fish allover the world. It occurs among various fish species predominatly in marine water, brackish water and freshwater fish. (Hacking and Budd, 1971; Kitao et al., 1983).

Losses from vibriosis have attained considerable importance and become a serious threat to fish production especially with the increasing utilization of sea, brackish and inland waters near the coast to cultivated and fatten fish of various species (Schaperclaus et al. 1992). Epizootics of vibriosis take place in fish in presence of overcrowding, poor hygiene and organical polluted water (Kitao et al., 1983; Noga, 1995). Vibrio is Gram-negative, non spore forming, facultative anaerobe and rod shaped bacterium, either currved or straight, it is motile by a single polar flagellum. Vibrio species grow in a wide temperature $5-35^{\circ} \mathrm{C}$ and rarely at $37^{\circ} \mathrm{C}$.It grows well on most common laboratory media in the presence of $3-10 \% \mathrm{NaCl}$. (Cowan et al., 1975).

Family Vibrionaceae including $V$. anguillarum, $V$. damsela, $V$. ordalii, V. vulnificus $V$. alginolyticus, V. fischeri and V. fluvialis (Oliver and kaper, 1997 and Hurley et al. 2006). Vibrio anguillarum is the most common fish pathogen that affecting fresh water as well as marine fishes (Hacking and Budd, 1971); Rock and Nelson, 2006).

Some Vibrios produce hemolysin which may cause anemia and proteases which may cause muscle damage, reducing the keeping quality, marketability of fish and so economically losses (Hjeltnes and Roberts, 1993).

Vibriosis among various fishes cause acute, subacute and chronic infection as well as external signs as erythema at the base of fins, in the mouth and along the grooves of the lower jaw (Bullock, 1987).

This investigation was planned to study the prevalence of vibrio species in Mugil cephalus fish, isolation and identification of the recovered Vibrios, pathogenicity to such fish and in vitro sensitivity to antibiograms. 


\section{MATERIALS and METHODS}

\section{Fish:}

A total number of 80 diseased fish (Mugil cephalus) (170g. \pm body weight) were collected from private fish farms in Dakahlia Governorate. Diseased fish showed wide spread skin and fin haemorrhages, sloughed skin, fin rot and anal congestion.

Fish specimens were transferred to laboratory and bacteriologically examined.

\section{Bacteriological examination:}

Specimens of fish gills, skin, liver, spleen and kidneys were taken under complete aseptic precautions for bacteriological examination of vibrio species according to Schaperclaus et al. (1992) and Austin and Austin, (1993). The samples were inoculated into Brain Heart Infustion (BHI) broth and peptone water containing 3\% sodium chloride tubes and adjusted at $\mathrm{pH} 8.5$ and incubated aerobically at $25^{\circ} \mathrm{C}$ over night. loopfuls from the inoculated tubes were streaked on (BHI) agar with 3\% sodium chloride. Moreover, Thiosulphate Citrate Bile Salt Sucrose agar (TCBS) was also used as a selective media and incubated at $25^{\circ} \mathrm{C}$ for 24 hours according to Inglis et al. (1993) and Quinn et al. (1994). The typical colonies were picked up on Trypticase Soya Agar (TSA) slant with 3\% $\mathrm{NaCl}$ and incubated at $25^{\circ} \mathrm{C}$ for 24 hours. The isolates were morphologically and biochemically identified by Gram-stain, oxidase and catalase tests, motility, carbohydrate fermentation, TSI slant and other biochemical tests according to Overman et al. (1985) and Elliot et al. (1995).

\section{Experimental infection:}

The isolates were grown separately on BHI broth for 24 hours, then $0.2 \mathrm{ml}$ dose $\left(5 \times 10^{5} \mathrm{CFU} / \mathrm{ml}\right)$ was intraperitoneally injected to Mugil cephalus fish (5 fish for each isolate).

Furthermore 5 fish were used as a control group. The inoculated fish were observed during 3-weeks for the development of pathological changes.

Reisolation of the inoculated organism from internal organs of freshly dead fish was carried out.

\section{Antibiogram activity:}

Bacterial isolates were tested for their susceptibility towards ten antibacterial agents according to Koneman et al. (1992) using the following drugs; Amoxycillin, Ampicillin, Enrofloxacin Colistin sulphate, Nitrofuration, Cefotaxime, Oxytetracycline, Erythromycin, 
Lincomycin and Tetracycline. The interpretatrion of results was carried according to Bio-Merieux Manual (1986).

\section{RESULTS}

Table 1: Biochemical properties of the isolated vibrio used for identification

\begin{tabular}{|c|c|c|c|c|c|c|c|c|c|c|c|c|}
\hline \multirow[b]{2}{*}{ Vibrio Strain } & \multicolumn{12}{|c|}{ Biochemical properties } \\
\hline & 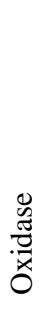 & 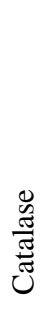 & 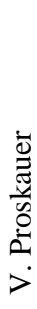 & 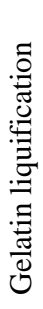 & 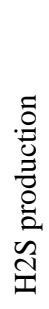 & 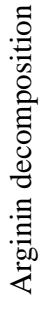 & 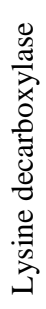 & 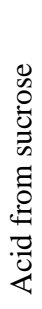 & 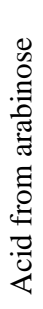 & 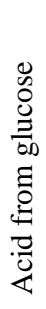 & 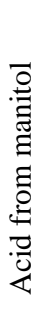 & 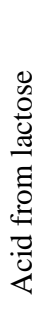 \\
\hline V. anguillarum & + & + & + & + & - & + & - & + & \pm & + & + & - \\
\hline V.ordalii & + & + & - & + & - & + & - & + & - & + & + & - \\
\hline V. damsela & + & + & - & \pm & - & + & \pm & - & - & - & - & - \\
\hline V. vulnificus & + & + & - & - & \pm & - & + & \pm & - & - & - & \pm \\
\hline
\end{tabular}

$+=$ positive $\quad-=$ Negative $\quad \pm=$ positive or negative

Table 2: Prevalence of Vibrio species in Mugil cephalus.

\begin{tabular}{|c|c|c|c|c|c|c|}
\hline \multirow{2}{*}{$\begin{array}{c}\text { No. of } \\
\text { examined } \\
\text { samples }\end{array}$} & \multicolumn{2}{|c|}{ Positive samples } & \multicolumn{4}{|c|}{ Vibrio species } \\
\cline { 2 - 7 } & No. & $\%$ & $\begin{array}{c}\text { V. } \\
\text { anguillarum } \\
\text { biotype } C\end{array}$ & $\begin{array}{c}\text { V. } \\
\text { ordalii }\end{array}$ & $\begin{array}{c}\text { V. } \\
\text { damsela }\end{array}$ & $\begin{array}{c}\text { V.vulnificus } \\
\text { group 2 }\end{array}$ \\
\hline 80 & 27 & 33.75 & 16 & 8 & 5 & 3 \\
\hline
\end{tabular}

Table 3: Recovery rate of Vibrio species among various organs of naturally infected Mugil cephalus

\begin{tabular}{|l|c|c|c|c|c|c|c|c|c|c|}
\hline \multicolumn{1}{|c|}{$\begin{array}{c}\text { Vibrio } \\
\text { species }\end{array}$} & \multicolumn{2}{|c|}{ Total isolates } & Gills & $\%$ & Liver & $\%$ & Spleen & $\%$ & Kidneys & $\%$ \\
\cline { 2 - 11 } $\begin{array}{l}\text { V. } \\
\text { anguillarum } \\
\text { biotype C }\end{array}$ & 16 & 59.25 & 3 & 18.75 & 7 & 43.75 & 4 & 25.00 & 2 & 12.50 \\
\hline V. ordalii & 8 & 29.62 & 2 & 25.00 & 3 & 37.50 & 2 & 25.00 & 1 & 12.50 \\
\hline V. damsela & 5 & 18.51 & 1 & 20.00 & 3 & 60.00 & 1 & 20.00 & 0 & 0.00 \\
\hline $\begin{array}{l}\text { V. } \\
\text { vulnificus } \\
\text { group 2 }\end{array}$ & 3 & 11.11 & 0 & 0.00 & 2 & 66.66 & 1 & 33.33 & 0 & 0.00 \\
\hline Total & 32 & & 6 & 18.75 & 15 & 46.87 & 8 & 25.00 & 3 & 9.37 \\
\hline
\end{tabular}


Table 4: Results of I/P experimental infection of Vibrio species in Mugil cephalus.

\begin{tabular}{|c|c|c|c|c|c|}
\hline Vibrio species & $\begin{array}{c}\text { No. of used } \\
\text { isolates }\end{array}$ & $\begin{array}{c}\text { No. of } \\
\text { inoculated } \\
\text { fish/isolate }\end{array}$ & $\begin{array}{c}\text { Total No. of } \\
\text { inoculated } \\
\text { fish }\end{array}$ & \multicolumn{2}{|c|}{ Total mortalities } \\
\cline { 5 - 6 } $\begin{array}{c}\text { anguillarum } \\
\text { biotype C }\end{array}$ & 2 & 5 & 10 & 8 & 80.00 \\
\hline V.ordalii & 2 & 5 & 10 & 7 & 70.00 \\
\hline $\begin{array}{c}\text { V. damsela } \\
\text { V. vulnificus } \\
\text { group 2 }\end{array}$ & 2 & 5 & 10 & 6 & 60.00 \\
\hline total & 8 & 5 & 10 & 4 & 40.00 \\
\hline
\end{tabular}

Table 5: Sensitivity of the isolated Vibrio species to different antibiograms

\begin{tabular}{|l|c|c|c|c|c|}
\hline \multicolumn{1}{|c|}{ Antibiograme } & $\begin{array}{c}\text { Disc } \\
\text { concentration }\end{array}$ & $\begin{array}{c}\text { V. } \\
\text { anguillarum } \\
\text { biotype C }\end{array}$ & $\begin{array}{c}\text { V. } \\
\text { ordalii }\end{array}$ & $\begin{array}{c}\text { V. } \\
\text { damsela }\end{array}$ & $\begin{array}{c}\text { V. } \\
\text { vulnificus } \\
\text { group 2 }\end{array}$ \\
\hline Amoxycillin & $10 \mathrm{ug}$ & $\mathrm{R}$ & $\mathrm{R}$ & $\mathrm{S}$ & $\mathrm{S}$ \\
\hline Ampicillin & $10 \mathrm{ug}$ & $\mathrm{R}$ & $\mathrm{R}$ & $\mathrm{R}$ & $\mathrm{R}$ \\
\hline Enrofloxacin & $10 \mathrm{ug}$ & $\mathrm{S}$ & $\mathrm{S}$ & $\mathrm{S}$ & $\mathrm{S}$ \\
\hline Colistin sulphate & $10 \mathrm{ug}$ & $\mathrm{S}$ & $\mathrm{S}$ & $\mathrm{S}$ & $\mathrm{S}$ \\
\hline Nitrofurantion & $300 \mathrm{ug}$ & $\mathrm{S}$ & $\mathrm{S}$ & $\mathrm{S}$ & $\mathrm{S}$ \\
\hline Cefotaxime & $30 \mathrm{ug}$ & $\mathrm{S}$ & $\mathrm{S}$ & $\mathrm{S}$ & $\mathrm{S}$ \\
\hline Oxytetracycline & $30 \mathrm{ug}$ & $\mathrm{S}$ & $\mathrm{S}$ & $\mathrm{S}$ & $\mathrm{S}$ \\
\hline Erythromycin & $15 \mathrm{ug}$ & $\mathrm{R}$ & $\mathrm{S}$ & $\mathrm{S}$ & $\mathrm{S}$ \\
\hline Lincomycin & $2 \mathrm{ug}$ & $\mathrm{R}$ & $\mathrm{R}$ & $\mathrm{R}$ & $\mathrm{R}$ \\
\hline Tetracycline & $30 \mathrm{ug}$ & $\mathrm{S}$ & $\mathrm{S}$ & $\mathrm{S}$ & $\mathrm{S}$ \\
\hline
\end{tabular}

S: sensitivity of the studies isolated of each vibrio species to antibiograme was $>50 \%$.

R: Sensitivity of the studies isolates of each vibrio species to antibiogram was $<50 \%$.

\section{DISCUSSION}

Vibrio spp. is a natural inhabitant of the fish. These organisms are considered food borne pathogens able to contaminate the fish causing world health problems and economic loss in fish industry. 
Not all strains of vibrio are considered pathogenic strains except that produce thermostable direct hemolysin (Bag et al., 1999).

The data presented in Table (2) indicated that the prevalence of vibrio species in Mugil cephalus was $33.75 \%$. The obtained prevalence are nearly similar with reported by Abd El-Gaber et al., (1997) who isolated vibrio species $37.50 \%$ from Mugil cephalus. In this study, recovered vibrio species were $V$. anguillarum biotype C 16 (59.25\%), $V$. ordalii 8(29.62\%), V. damsela 5 (18.51\%) and V. vulnificus groups 2, 3 (11.11\%). On the other hand, Abd El-Gaber et al., (1997) isolated V. anguillarum biotype C. (34.37\%), V. ordalii (28.12\%), V. damsela (21.87\%) and V. vulnificus group 2 (15.62\%) from Mugil cephalus fish.

In the present study $V$. anguillarum which constituted the highest prevalence rate $16(59.25 \%)$ was recovered from Mugil cephalus as shown in Tables (2) and (3). This is in nearly agreement with most other studies Muroga and Egusa 1988; Rock and Nelson 2006 and ChaiYingmei et al., 2006). Such results were high as compared with those reported by Abd El-Gaber et al.,1997) who isolated V. anguillarum biotype C 5 (15.62\%) from Mugil cephalus while high results were recorded by Moustafa et al., (1990) who isolated V. anguillarum type A from $74.00 \%$ of Mullet fish (Mugil cephalus).

The highest isolation rate could be attributed to environemental stresses particularly high water temperature, organically polluted water, high salinity and poor hygiene and handling resulting in depression of one or several defensive mechanisms (Ellis, 1981). This finding was supported by Moustafa et al., (1990) who recorded that water pollution and high salinity were the major stress factors for occurrence of vibriosis among fishes.

Concerning the site of isolation from Mugil cephalus fish, vibrios were high from liver 15 isolates $(46.87 \%)$ followed by spleen 8 isolates (25.00\%), gills 6 isolates (18.75\%) and kidneys 3 isolates $(9.37 \%)$ Table (3) .On the other hand, Abd El Gaber et al., (1997) isolated Vibrios from liver, spleen, kidneys and gills of Mugil cephalus fish with percentage of $35.00,37.50,30.00$ and $22.50 \%$ respectively.

Regarding to the experimental infection of Mugil cephalus with different vibrio species Table (4), exhibited a septicaemic picture within one week post intraperitoneal injection where $62.50 \%$ of inoculated fish were dead. Mortality rate ranged from $40.00 \%$ with $V$. vulnificus gp. 2 to $80.00 \%$ with $V$. anguillarum biotype $C$. while $V$. ordalii produced $70.00 \%$ mortalities and $V$. damsela $60.00 \%$ These findings were supported by Abd El-Gaber et al., (1997) who recorded 70\% mortalities 
among $O$. niloticus with different Vibrio species. El-Bouhy et al., (1990) found $80 \%$ mortalities was reported after interperitoneal infection of Nile catfish with $V$. anguillarum and Amany et al., (2000) recorded 90\% mortalities among C. lazera post. interaperitoneal infection of $V$. anguillarum.

Moreover, clinical signs and gross lesions induced by Vibrios in the present sudy were nearly similar to thoses observed in Abd El Gaber et al., (1997).Nearly similar observations were also recorded in other fish species which had Vibriosis Austin and Austin (1989); Lavilla pitogo et al., (1992) and Schaperclaus et al., (1992).

As shown in Table (5), Vibrio species were sensitive to Enrofloxacin, Colistin sulphate, Nitrofuratoin, Oxytetra-cycline, Tetracycline and Cefotaxime. They resistance to Lincomycin and Erythromycin. These results nearly agreed with that recorded by different authors (Balsgaard and Bjerregaard 1991; Austin and Austin 1993; Shaahan et al. 1995; Yonis et al., 1997; Abd El Gaber et al., 1997; Zeinab Soliman 1999 and Amany et al., 2000) who found that the isolated $V$. anguillarum strain was sensitive to Ampicillin and Chlormphenicol, while it was resistant to Erythromycin Joklik et al. (1992) and Stephens et al. (2006) recorded that most isolates of $V$. damsela were sensitive to Tetracycline.

It was concluded that Vibrio species existed in the examined fishes in varying percentages. $V$. anguillarum is the most serious pathogen of freshwater fish (M. cephalus) and it was highly pathogenic when injected in healthy ones and prevent the infections by Good handling, hygienic measurement and prevention the source of water pollution, also administration of the effective drug to fish should be carefully controlled on Vibriosis.

\section{REFERENCES}

Abdel-Gaber, G.; Naguib, M. and Abdel-Aziz, E.S. (1997): Vibrio species infections to Oreochromis niloticus and Mugil cephalus; Sodium chloride tolerance, pathogenicity, serological relatedness and antibiogram sensitivity of recovered vibrios. Vet. Med. J., Giza. 45 (1): 87-99.

Amany, A. abbass; Shaheen, A.A; Abd El-Azizi, A. Mosaad and Mona, M. Sobhy (2000): Clinicopathological and laboratory investigations on vibriosisi in some fishes. Zag. Vet. J. (ISSN. 1110- 1458) Vol. 28, No. 3, PP. 115 - 124. 
Austin, B. and Austin, D.A. (1989): Methods for microbiological examination of fish and shellfish. Ellis Harwood Limited ,Chichester, England,p.317.

Austin, B. and Austin, D.A. (1993): Bacterial Fish Pathogens. Disease in Farmed and wild Fish. 2nd. ed, Printed and bound in Great Britain by Hartnolls, . Bodmin.

Bag, P.; Nandi, S.; Bhardra, R.; Ramamurthy, T; Bhattacharya, S; Nishibuchi, M.; Hamabota, T.; Yamasaki, S.; Takeda, Y. and Nair,G. (1999); Clonal diversity among recently emerged strains of Vibrio parahaemolyticus O3:K6 associted with pandemic spread. J. Clic. Microbiol. 37: 2345-2357.

Balsgaard, I. and Bjerregaard, J. (1991): Enrofloxacin an antibiotic in fish. Acta Vetrinaria Scendinavica Supplementum. 87, 300301.

Bio-merieux (1986): Laboratory reagents and products Bacteriology Barcy-L. Etoile 69260 charbon-mieres Le-Bains, France.

Bullock, G. (1987): Vibriosis in fish. United State Department of the Interior, Fish and Wildlife Service, Division of Fisheries and Wetlands Research, Washington, D.C. 20240

Chai- Yingmei; Huang-XiaoHang; Cong-Bailin; Liu-Sheng Hao; Chenkui; Li-Guang you and Gaisano, H.Y. (2006): Involvement of Vamp- 2 in exocytosis of IL- I beta in turbot (Scophthalmus maximus) Leukocytes after Vibrio anguillarum. Biochemical and Biophysical Research communication. 342(2): $509-513$.

Cowan, S.T.; Holt, J.G.; Liston, J.; Murray, R.G.E.; Niven; C.F.; Ravin, A.W. and Stanier, R.W. (1975): In Buchanen, R.E. and N.E. Gibbons. Eds. Bergey's manual of determinative bacteriology $8^{\text {th }}$ Ed. Williams \& Wilkins Co., Baltimore, MD, 1, 268p.

El-Bouhy, Z.M.; Abdel-Monem, AA.; Mohamed, E. and Moustafa, M.B. (1990): Preliminary studies on vibrios in some freshwater fishes. Zagazig Vet. J. 18 (5): 68-86.

Elliot, E.; Kaysner, C.; Jackson, L. and Tamplin, M. (1995): Vibrio Cholera, V. parahaemolyticus, V. vulnificus and other Vibrio spp. pp. 9.01-9.27. In FDA Bacteriological Analytical Manual, $8^{\text {th }}$ Ed. AOAC International, Gaithersburg, MD.

Ellis, A.E. (1981): Stresses and modulation of the immune response in fish. In stress and fish, Academic press, London. PP. 147-169.

Hacking, M.A. and Budd, J. (1971): Vibrio infection in tropical fish in a freshwater aquarium. J. Wildlife Dis. 7: 273-280. 
Hjeltnes B. and Robots, R.J. (1993): Bacterial diseases of fish, New York, Halsted Press, PP. 109-121.

Hurley, C.; Quirke, A.; Reen, F. and Boyd, E. (2006): Four genomic islands that mark post-1975 pandemic Vibrio parahaemolyticus isolates. BMC Genomic, 3 (7): 104.

Inglis, V.; Oberts, R.J. and Bromage, N.R. (1993): Bacterial diseases of fish. Oxford Blackwell Scientific Publications, London, Edinburgh, Bosten, Mellbournce. Paris, Berlin, Vienna.

Joklik, W.K.; Willett, H.P.; Amos, D.B. and Wilfert, C.M. (1992): Zinsser Microbiology. 20th Edition. Appleton \& Lange. Norwalk, Connecticut/San Mateo, California.

Kitao, T.; Roberts, R.G. and Bromage, N.R. (1983): Serotyping of Vibrio anguillarum isolated from fresh water fish in Japan. J. Fish Dis., 6: $175-181$.

Koneman, E.W.; Allen, S.D.; Janda, W.M.; Schreckenberger, P.C. and Winn, W.C.Tr. (1992): Colour Atlas and Textbook of Diagnostic Microbiology. $4^{\text {th }}$ Ed., L[pincott company, Philadelphia USA.

Lavilla-Pitogo, C.R.; Castillo, A.R. and De La Cruz, M.C. (1992): Occurrence of Vibrio species infection in Grouper, Epinephelus suillus. J. Appl. Ichthyol., 8 (1/4), 175-179.

Moustafa, M.; Eissa, I.A.M. and Hanafi, M.S. (1990): Vibriosis in marine fishes of Qarun lake. Zagazig Vet. J., 18 (195):94-105.

Muroga, K. and Egusa, S. (1988): Vibriosis of ayu. J. Appl. Biolog. Sci., Hiroshima University, 27 (1): 1-17.

Noga, E.J. (1995): Fish disease: Diagnosis and treatments. $1^{\text {st }}$ ed., Wals worth Publishing Co., USA. PP. 149.

Oliver, J. and Kaper, J. (1997): Vibrio species. In M. P. Doyle, L. R. Beuchat and T.J. Montville, Eds. Food Microbiology: Fundamentals and Frontiers, p 228-264. Washington, D.C., ASM Press.

Overman, T.; Kessler, J. and Seabolt, J. (1985): Comparison of API20E, API Rapid E and API. Rapid NFT for identification of members of the family Vibrionaceae. J. Clin. Microbiol. 22: $778-781$.

Quinn, P.J.; Carter, M.E.; Markey, B.K. and Carter, G.R. (1994): Clinical Veterianry Microbiology. Published by welfe Publishing. 
Rock, J.L. and Nelson, D.R. (2006): Identification and characterization of a hemolysin gene cluster in Vibrio anguillarum. Infection and immunity 74(5): 2777- 2786.

Schaperclaus, W.; Kulow, H. and Schreckenbach, K. (1992): Fish Diseases. Vol. 1, 5th corrected, revised and substantially enlarged edition. A.A. Balkema. Roterdam.

Shaaban, A.I.; Easa El-S.M. and Diab, S.A. (1995): Characterization of $\mathrm{V}$. anguillarum isolated from wild fish eels (Anguilla japanica) in Egypt. J. Egypt. Vet. Med. Ass., 55 (1, 2): 141-145.

Stephens, F.J.; Raidal, S.R.; Buller, and Jones, B. (2006): Infection with Photobacterium damselae subspecies damsela and Vibrio harveyi in snapper, Pagrus auratus with bloat. Australian Vet. J. 84 (5): 173 - 177.

Yonis A.A.; Amer, M.M.; Azizi Naguib M. and Abdel-Azizi E.S. (1997): Pharmacokinetics, efficacy and tissue residues of enrofloxacin in Oreochromis niloticus infected with Vibrio anguillarum. Vet. Med. J. Giza 45(1). 75 - 85.

Zeinab, I. soliman (1999): Antibiogram of some bacteria contaminating Tilapia fish at El- Manzala lake in Port-Said Governorate. Vet. Med. J., Giza. 47 (1): 19 - 27 